\title{
Faktor risiko stunting pada anak umur 6-24 bulan di kecamatan Penanggalan kota Subulussalam provinsi Aceh
}

\author{
Wanda Lestari ${ }^{1}$, Ani Margawati ${ }^{2}$, M. Zen Rahfiludin ${ }^{3}$
}

\begin{abstract}
Background: Aceh is one of the provinces in Indonesia with high prevalence of stunting that is 39\% compared with national $35,6 \%$. Subulussalam city has a highly proportion of stunting.

Objective : This study was aimed to analyze the risk factors for stunting among children between 6-24 months old.

Methods: The design was case-control study; the subjects were children between 6-24 months with 55 stunted and 55 normal. Subjects were chosen by consecutive sampling method. The risk factors were education levels and employment of parent, family income, suffering from diarrhea and upper track respiratory infection (UTRI), energy and protein intake, height of the parent, birth weight, exclusive breastfeeding, the time of complementary feeding, parenting and source of clean water. Data was analyzed using the odds ratio with $95 \%$ confidence interval and regression analysis.

Results: The risk factors for stunting were low income of family (OR=8,5, 95\%CI: 2,68-26,89), suffering from diarrhea $(O R=5,04,95 \% C I: 1,84-13,81)$ and UTRI (OR=5,71, 95\%CI: 1,95-16,67), inadequate of energy (OR=3,09, 95\%CI: 1,029,39) and protein intake (OR=5,54, 95\% CI: 2,43-12,63), short stature of the parent $(O R=11,13,95 \%$ CI: 4,37-28,3), low birth weight $(O R=3,26,95 \% \mathrm{CI}: 1,46-7,31)$, not exclusively breastfeeding (OR=6,54, 95\%CI: 2,84-15,06), giving complementary feeding too early $(O R=6,54,95 \% C I: 2,84-15,06)$, and poor parenting style of feeding practices $(O R=4,59,95 \% C I: 2,05-$ 10,25), child hygiene practices $(O R=3,26,95 \% C I: 1,46-7,31)$ and treatment of children practices $(O R=2,46,95 \% C I: 1,13-$ 5,34). Regression analysis showed that the dominant risk factor for stunting was short stature of the parent $(O R=13,16$, 95\% CI: 3,72-46,52).
\end{abstract}

Conclusions: The dominant risk factor for stunting was short stature of the parent.

Keywords: stunting, $6-24$ children, parents height

\section{ABSTRAK}

Latar belakang: Aceh merupakan salah satu provinsi dengan prevalensi stunting yang tinggi. Prevalensi stunting di wilayah tersebut mencapai 39\% lebih tinggi dibanding prevalensi nasional 35,6\%.

Tujuan: Penelitian ini bertujuan mengalanisis faktor-faktor risiko stunting anak usia 6 - 24 bulan di provinsi Aceh.

Metode: Penelitian ini merupakan studi kasus control, dengan subjek adalah anak usia 6 - 24 bulan. Sebanyak 55 anak pendek dan 55 anak normal menjadi subjek penelitian ini. Subjek dipilih dengan metode consecutive sampling. Faktor risiko yang diukur adalah pendidikan orang tua, pekerjaan orang tua, pendapatan keluarga, riwayat sakit diare dan infeksi saluran napas atas, asupan energi dan protein, tinggi badan orang tua, berat lahir, pemberian ASI eksklusif, waktu pemberian pendamping ASI, pola asuh orang tua dan sumber air bersih. Data dianalisis dengan regresi.

Hasil: Faktor risiko stunting pada keluarga berpenghasilan rendah (OR =8,5, 95\% CI: 2,68-26,89), yang menderita diare $(O R=5,04,95 \%$ CI: 1,84-13, 81) dan ISPA $(O R=5,71,95 \%$ CI: 1,95-16,67), asupan energi tidak adekuat $($ OR $=3,09,95 \%$ CI: 1,02-9,39) dan asupan protein tidak adekuat $(O R=5,54,95 \%$ CI: 2,43-12,63), perawakan pendek dari orang tua $(O R=$ 11,13, 95\% CI: 4,37-28,3), berat badan lahir rendah $(O R=3,26,95 \%$ CI: 1,46-7,31), tidak menyusui ASI eksklusif $($ OR $=$ 6,54, 95\% CI: 2,84-15,06), memberikan makanan pendamping ASI terlalu cepat (OR = 6, 54, 95\% CI: 2,84-15,06), dan pola asuh kurang $(O R=4,59,95 \% C I: 2,05-10,25)$, praktik-praktik kebersihan anak $(O R=3,26,95 \%$ CI: 1,46-7,31) dan penanganan pengobatan anak $(O R=2,46,95 \% C I: 1,13-5,34)$. Analisis regresi menunjukkan bahwa faktor risiko yang dominan untuk stunting adalah perawakan pendek dari orang tua $(O R=13,16,95 \%$ CI: 3,72-46,52).

Simpulan: Perawakan pendek orang tua sebagai faktor risiko paling dominan terhadap stunting

Kata kunci: stunting, anak usia 6 - 24 bulan, perawakan pendek orang tua

\section{PENDAHULUAN}

Kekurangan gizi dapat diartikan sebagai suatu proses kekurangan asupan makanan ketika kebutuhan normal terhadap satu atau beberapa zat gizi tidak terpenuhi. ${ }^{1}$ Dampak kekurangan gizi kronis yaitu anak tidak dapat

\footnotetext{
${ }^{1}$ STIKes Helvetia Medan

${ }^{2}$ Fakultas Kedokteran UNDIP

${ }^{3}$ Fakultas Kesehatan Masyarakat UNDIP

Korespondensi : lonedalestari@yahoo.co.id
}

mencapai pertumbuhan yang optimal. Keadaan ini jika berlangsung secara terus menerus dapat mengakibatkan stunting. ${ }^{2}$ Stunting menggambarkan riwayat kekurangan gizi yang terjadi dalam jangka waktu yang lama.

Stunting pada anak mengakibatkan penurunan sistem imunitas tubuh dan meningkatkan risiko terkena penyakit infeksi. Kecenderungan untuk menderita penyakit tekanan darah tinggi, diabetes, 
jantung dan obesitas akan lebih tinggi ketika anak stunting menjadi dewasa. ${ }^{3}$ Anak stunting mempunyai rata-rata IQ 11 point lebih rendah dibandingkan ratarata anak yang tidak stunting. Penelitian di Wonogiri pada anak SD umur 9-12 tahun menunjukkan bahwa anak yang stunting memiliki risiko 9,2 kali lebih besar untuk memiliki nilai IQ di bawah rata-rata, dan ratarata prestasi belajar lebih rendah dibandingkan dengan anak yang tidak stunting., ${ }^{4,5,6}$

Faktor risiko terjadinya stunting yaitu asupan gizi yang kurang, berat lahir anak yang rendah, tinggi ibu, dan status ekonomi keluarga. ${ }^{7,8}$ Tingkat pendidikan orang tuan yang rendah juga berhubungan dengan stunting pada balita. ${ }^{9,10}$ Ayah yang tidak bekerja juga merupakan faktor risiko stunting. ${ }^{7,9}$

Penelitian lain menyebutkan bahwa faktor risiko stunting yang lain yaitu ASI eksklusif ${ }^{11}$ dan umur pemberian MP-ASI. ${ }^{12}$ Pola asuh orang tua berhubungan dengan kejadian stunting pada anak umur $6-12$ bulan. ${ }^{13}$ Anak yang sering menderita diare lebih berisiko untuk menjadi stunting. ${ }^{14}$ Penelitian kohort pada anak umur 6 bulan selama 1,5 tahun di India menunjukkan bahwa terjadi peningkatan prevalensi stunting pada anak yang diberikan perlakuan konsumsi air biasa. ${ }^{15}$

Aceh merupakan salah satu provinsi dengan prevalensi balita stunting yang tinggi yaitu 39\% dibandingkan angka nasional 35,6\%. ${ }^{16}$ Subulussalam merupakan daerah dengan kejadian stunting yang tinggi pada balita. Tujuan penelitian untuk menganalisis faktor-faktor risiko kejadian stunting pada anak umur 6-24 bulan di Kecamatan Penanggalan Kota Subulussalam.

\section{METODE DAN BAHAN}

Desain penelitian adalah kasus-kontrol. Sampel penelitian adalah 55 anak stunting dan 55 anak normal yang memenuhi kriteria inklusi. Penentuan sampel dengan cara concequtive sampling. Total anak yang diukur adalah 144 anak dan yang bersedia menjadi sampel adalah 110 anak.

Data yang dikumpulkan yaitu panjang badan anak dan tinggi badan orang tua. Variabel penelitian yaitu pekerjaan orang tua, pendapatan keluarga, menderita diare dan ISPA, tinggi badan orang tua, berat bayi lahir, ASI eksklusif, umur pemberian MP-ASI pertama kali, praktek pemberian makan, praktek kebersihan anak, praktek pengobatan anak, dan ketersediaan sumber air bersih diperoleh melalui wawancara dengan kuesioner. Data asupan energi dan protein anak diperoleh melalui food recall kepada ibu. Analisis data dengan nilai Odds Ratio untuk melihat faktor risiko apa sajakah yang menyebabkan stunting pada anak umur 6-24 bulan dengan 95\% Confidence Interval dan analisis regresi logistik.

\section{HASIL}

\section{Analisis Univariat}

Sampel penelitian sebagian besar berada pada umur 12-24 bulan dengan proporsi stunting lebih banyak terjadi pada anak laki-laki. Tingkat pendidikan ayah dan ibu sebagian besar yaitu tamat SMA. Pekerjaan ayah sebagian besar adalah petani/buruh sebanyak 36,36\% sedangkan pekerjaan ibu sebagian besar sebagai ibu rumah tangga sebesar $38,18 \%$. Pengeluaran keluarga secara umum tergolong ke dalam pengeluaran yang tinggi. Secara umum, sampel penelitian tidak menderita diare dan ISPA dalam 2 bulan terakhir. Tingkat kecukupan energi sampel tergolong dalam kategori kurang sebesar 83,64\% sedangkan sebesar $54,55 \%$ anak memiliki tingkat kecukupan protein yang baik. Sebagian besar sampel berasal dari kedua orang tua dengan tinggi badan normal.

Sampel penelitian sebesar $60,91 \%$ memiliki berat badan lahir yang normal. Lebih dari setengah sampel tidak mendapatkan ASI eksklusif dan diberikan MPASI dalam usia yang terlalu dini. Secara umum, pola asuh yang dilakukan oleh ibu sudah baik yaitu dalam hal praktek pemberian makan, praktek kebersihan, dan praktek pengobatan. Mayoritas rumah tangga memiliki sumber air yang berasal dari air ledeng. Karakteristik variabel penelitian dapat dilihat pada Tabel 1.

\section{Analisis Bivariat}

Hasil analisis bivariat dapat dilihat pada Tabel 2. Proporsi anak stunting lebih banyak terjadi pada anak yang memiliki ayah dengan pendidikan di bawah 9 tahun. Hal yang sama juga dapat dilihat pada variabel pendidikan ibu. Anak stunting lebih banyak terjadi pada anak yang memiliki ibu dengan tingkat pendidikan di bawah 9 tahun.

Kelompok anak yang stunting memiliki ayah dengan status bekerja. Proporsi anak stunting hampir setengahnya terjadi pada ibu yang tidak bekerja.

Proporsi anak yang stunting lebih banyak terjadi pada rumah tangga dengan pendapatan keluarga yang tergolong rendah. Nilai OR=8,5 (95\% CI: 2,68-26,89), $\mathrm{p}=0,001$.

Anak stunting lebih banyak terjadi pada anak yang menderita diare dalam 2 bulan terakhir. Nilai $\mathrm{OR}=5,04$ (95\% CI: 1,84-13,81), $\mathrm{p}=0,001)$. Hal yang sama dapat dilihat pada variabel ISPA.

Anak stunting pada penelitian ini memiliki proporsi yang lebih tinggi menderita ISPA dibandingkan dengan anak normal. Nilai $\mathrm{OR}=5,71$ (95\% CI: 1,95-16,67), $\mathrm{p}=0,001$. 
Tabel 1. Karakteristik Variabel Penelitian

\begin{tabular}{|c|c|c|c|}
\hline Karakteristik & Stunting $(\%) \mathrm{n}=55$ & Normal $(\%) n=55$ & Total $(\%) \mathrm{n}=110$ \\
\hline \multicolumn{4}{|l|}{ Usia anak } \\
\hline $7-11$ bulan & $18(32,73)$ & $14(25,45)$ & $32(29,09)$ \\
\hline 12-24 bulan & $37(67,27)$ & $41(74,55)$ & $78(70,91)$ \\
\hline \multicolumn{4}{|l|}{ Jenis kelamin } \\
\hline Laki-laki & $28(50,9)$ & $26(47,3)$ & $54(49,1)$ \\
\hline Perempuan & $27(49,1)$ & $29(52,7)$ & $56(50,9)$ \\
\hline \multicolumn{4}{|l|}{ Pendidikan Ayah } \\
\hline Tamat PT & $6(10,91)$ & $14(25,45)$ & $20(18,18)$ \\
\hline Tamat SMA & $25(45,45)$ & $26(47,27)$ & $51(46,36)$ \\
\hline Tamat SMP & $14(25,45)$ & $11(20)$ & $25(22,72)$ \\
\hline Tamat SD & $7(12,73)$ & $2(3,64)$ & $9(8,2)$ \\
\hline Tidak Tamat SD & $3(5,46)$ & $2(3,64)$ & $5(4,54)$ \\
\hline \multicolumn{4}{|l|}{ Pendidikan Ibu } \\
\hline Tamat PT & $5(9,1)$ & $8(14,54)$ & $13(11,82)$ \\
\hline Tamat SMA & $27(49,1)$ & $32(58,18)$ & $59(53,64)$ \\
\hline Tamat SMP & $18(32,72)$ & $11(20)$ & $29(26,36)$ \\
\hline Tamat SD & $4(7,27)$ & $3(5,46)$ & $7(6,36)$ \\
\hline Tidak Tamat SD & $1(1,81)$ & $1(1,82)$ & $2(1,82)$ \\
\hline \multicolumn{4}{|l|}{ Pekerjaan Ayah } \\
\hline PNS/POLRI/TNI & $7(12,73)$ & $12(21,82)$ & $19(17,27)$ \\
\hline Pegawai swasta/karyawan & $6(10,91)$ & $11(20)$ & $17(15,45)$ \\
\hline Pedagang/wiraswasta & $18(32,73)$ & $15(27,27)$ & $33(30)$ \\
\hline Petani/buruh & $24(43,63)$ & $16(29,1)$ & $40(36,36)$ \\
\hline Tidak bekerja & - & $1(1,81)$ & $1(0,92)$ \\
\hline \multicolumn{4}{|l|}{ Pekerjaan Ibu } \\
\hline PNS/POLRI/TNI & $2(3,64)$ & $8(14,54)$ & $10(9,09)$ \\
\hline Pegawai swasta/karyawan & $6(10,91)$ & $4(7,27)$ & $10(9,09)$ \\
\hline Pedagang/wiraswasta & $11(20)$ & $12(21,82)$ & $23(20,91)$ \\
\hline Petani/buruh & $12(21,82)$ & $13(23,64)$ & $25(22,73)$ \\
\hline Tidak bekerja & $24(43,64)$ & $18(32,73)$ & $42(38,18)$ \\
\hline \multicolumn{4}{|l|}{ Pengeluaran Keluarga } \\
\hline Rendah & $22(40)$ & $4(7,3)$ & $26(23,64)$ \\
\hline Tinggi & $33(60)$ & $51(92,7)$ & $84(76,36)$ \\
\hline \multicolumn{4}{|l|}{ Frekuensi Diare } \\
\hline Pernah sakit/2 bln & $21(38,18)$ & $6(10,91)$ & $27(24,55)$ \\
\hline Tidak pernah sakit/2 bln & $34(61,82)$ & $49(89,09)$ & $83(75,45)$ \\
\hline \multicolumn{4}{|l|}{ Frekuensi ISPA } \\
\hline Pernah sakit/2 bln & $20(36,36)$ & $5(9,09)$ & $25(22,73)$ \\
\hline Tidak pernah sakit/2 bln & $35(63,64)$ & $50(90,91)$ & $85(77,27)$ \\
\hline \multicolumn{4}{|l|}{ Tingkat Kecukupan Energi } \\
\hline Kurang & $50(90,9)$ & $42(76,4)$ & $92(83,64)$ \\
\hline Baik & $5(9,1)$ & $13(23,6)$ & $18(16,36)$ \\
\hline \multicolumn{4}{|l|}{ Tingkat Kecukupan Protein } \\
\hline Kurang & $36(65,5)$ & $14(25,5)$ & $50(45,45)$ \\
\hline Baik & $19(34,5)$ & $41(74,5)$ & $60(54,55)$ \\
\hline \multicolumn{4}{|l|}{ Tinggi Badan Orang Tua } \\
\hline Pendek/salah satu pendek & $36(65,5)$ & $8(14,5)$ & $44(40)$ \\
\hline Normal & $19(34,5)$ & $47(85,5)$ & $66(60)$ \\
\hline \multicolumn{4}{|l|}{ Berat Bayi Lahir } \\
\hline$<2500$ gram & $29(52,7)$ & $14(25,5)$ & $43(39,09)$ \\
\hline$\geq 2500$ gram & $26(47,3)$ & $41(74,5)$ & $67(60,91)$ \\
\hline
\end{tabular}


Tabel 1. Karakteristik Variabel Penelitian (lanjutan)

\begin{tabular}{lccc}
\hline \multicolumn{1}{c}{ Karakteristik } & Stunting $(\%) \mathrm{n}=55$ & Normal $(\%) \mathrm{n}=55$ & Total $(\%) \mathrm{n}=110$ \\
\hline ASI Eksklusif & & & \\
Tidak & $41(74,5)$ & $17(30,9)$ & $58(52,73)$ \\
Ya & $14(25,5)$ & $38(69,1)$ & $52(47,27)$ \\
\hline Umur Pemberian MP-ASI & & & \\
Terlalu Dini & $41(74,5)$ & $17(30,9)$ & $58(52,73)$ \\
Normal & $14(25,5)$ & $38(69,1)$ & $52(47,27)$ \\
\hline Praktek Pemberian Makan & & & \\
Kurang & $37(67,3)$ & $17(30,9)$ & $54(49,09)$ \\
Baik & $18(32,7)$ & $38(69,1)$ & $56(50,91)$ \\
\hline Praktek Kebersihan & & & \\
Kurang & $29(52,7)$ & $14(25,5)$ & $43(39,09)$ \\
Baik & $26(47,3)$ & $41(74,5)$ & $67(60,91)$ \\
\hline Praktek Pengobatan & & & \\
Kurang & $30(54,5)$ & $17(30,9)$ & $47(42,73)$ \\
Baik & $25(45,5)$ & $38(69,1)$ & $63(57,27)$ \\
\hline Sumber Air & & & \\
Air ledeng & $31(56,36)$ & $38(69,1)$ & $69(62,73)$ \\
Sumur & $19(34,54)$ & $14(25,45)$ & $33(30)$ \\
Sungai & $5(9,1)$ & $3(5,45)$ & $8(7,27)$ \\
\hline
\end{tabular}

Rendahnya tingkat kecukupan energi dan protein merupakan faktor risiko stunting pada penelitian ini. Anak stunting lebih banyak terjadi pada anak dengan tingkat kecukupan energi kurang. Nilai $\mathrm{OR}=3,09$ (95\% CI: 1,02-9,39), $\mathrm{p}=0,03$, sedangkan untuk tingkat kecukupan protein nilai $\mathrm{OR}=5,54(95 \% \mathrm{CI}$ : 2,43-12,63), $\mathrm{p}=0,001$.

Faktor risiko lain anak stunting pada penelitian ini yaitu orang tua yang pendek adalah $65,5 \%$. Nilai $\mathrm{OR}=11,13(95 \%$ CI: 4,37-28,3), p=0,0001, artinya orang tua yang pendek merupakan faktor risiko kejadian stunting pada anak umur 6-24 bulan. Anak yang dilahirkan < 2500 gram berisiko untuk menjadi stunting (OR=3,26, 95\% CI: 1,46-7,31, $\mathrm{p}=0,003)$.

Proporsi anak stunting juga lebih tinggi terjadi pada anak yang tidak diberi ASI eksklusif dan MPASI diberikan terlalu dini, terlihat dari nilai OR yang sama. Ada hubungan antara ASI eksklusif dan umur pemberian MP-ASI. Nilai OR yaitu 6,54 (95\% CI: 2,84-15,06), $\mathrm{p}=0,0001$.

Anak stunting sebagian besar terjadi karena anak mendapatkan pola asuh yang kurang dalam hal praktek pemberian makan $(\mathrm{OR}=4,59,95 \% \mathrm{CI}: 2,05-$ $10,25, \mathrm{p}=0,0001)$, praktek kebersihan $(\mathrm{OR}=3,26$, $95 \%$ CI: $1,46-7,31, \mathrm{p}=0,003)$, serta praktek pengobatan ( $\mathrm{OR}=2,46,95 \% \mathrm{CI}: 1,13-5,34, \mathrm{p}=0,02)$. Anak stunting dengan rumah tangga yang memiliki ketersediaan sumber air bersih tidak layak sebesar $9,1 \%$. Nilai $\mathrm{OR}=1,73(0,39-7,63), \mathrm{p}=0,46$, artinya ketersediaan sumber air bersih yang tidak layak bukan merupakan faktor risiko kejadian stunting pada anak umur 6-24 bulan.

\section{Analisis Multivariat}

Variabel yang dimasukkan ke dalam analisis regresi logistik yaitu variabel yang memiliki nilai $\mathrm{p}<$ 0,25 dan bermakna secara statistik. Variabel tersebut adalah pendapatan keluarga yang rendah, menderita diare, menderita ISPA, tingkat kecukupan energi rendah, tingkat kecukupan protein rendah, tinggi badan orang tua, berat bayi lahir rendah, tidak diberi ASI eksklusif, MP-ASI diberikan terlalu dini, pola asuh yang kurang. Hasil analisis regresi logistik dapat dilihat pada tabel 3 .

Hasil analisis menunjukkan bahwa terdapat enam variabel yang merupakan faktor risiko kejadian stunting pada anak umur 6-24 bulan. Faktor risiko yang paling tinggi yaitu kedua orang tua yang pendek atau salah satu pendek

\section{PEMBAHASAN}

Pendidikan ayah di bawah 9 tahun bukan merupakan faktor risiko kejadian stunting. Hal ini sejalan dengan penelitian pada balita stunting di Maluku bahwa rendahnya pendidikan ayah bukan merupakan faktor risiko stunting. ${ }^{7}$ Bertolak belakang dengan penelitian lain, ada hubungan yang signifikan antara tingkat pendidikan ayah dengan kejadian stunting pada balita di Turki. ${ }^{9}$

Tingkat pendidikan ayah pada penelitian ini untuk kedua kelompok sebagian besar adalah tamatan SMA. Latar belakang pendidikan SMA merupakan tingkat pendidikan yang tergolong tinggi sehingga 
Tabel 2. Faktor Risiko Stunting ; Analisis Bivariat

\begin{tabular}{|c|c|c|c|c|}
\hline Variabel & Kasus $n=55$ & Kontrol $n=55$ & Total $(\%) \mathrm{n}=110$ & $\mathrm{OR}(95 \% \mathrm{CI})$ \\
\hline \multicolumn{5}{|l|}{ Pendidikan Ayah } \\
\hline Rendah & 24 & 15 & $39(35,5)$ & 2,06 \\
\hline Tinggi & 31 & 40 & $71(64,5)$ & $(0,93-4,58)$ \\
\hline \multicolumn{5}{|l|}{ Pendidikan Ibu } \\
\hline Rendah & 23 & 15 & $38(34,5)$ & 1,91 \\
\hline Tinggi & 32 & 40 & $72(65,4)$ & $(0,86-4,26)$ \\
\hline \multicolumn{5}{|l|}{ Pekerjaan Ayah } \\
\hline Tidak Bekerja & 0 & 1 & $1(0,91)$ & 2,01 \\
\hline Bekerja & 55 & 54 & $109(99,09)$ & $(1,67-2,44)$ \\
\hline \multicolumn{5}{|l|}{ Pekerjaan Ibu } \\
\hline Tidak Bekerja & 24 & 18 & $42(38,2)$ & 1,59 \\
\hline Bekerja & 31 & 37 & $68(61,8)$ & $(0,73-3,45)$ \\
\hline \multicolumn{5}{|l|}{ Pendapatan Keluarga } \\
\hline Rendah & 22 & 4 & $26(23,6)$ & 8,5 \\
\hline Tinggi & 33 & 51 & $84(76,4)$ & $(2,68-26,89)$ \\
\hline \multicolumn{5}{|l|}{ Menderita Diare } \\
\hline Pernah sakit & 21 & 6 & $27(24,5)$ & 5,04 \\
\hline Tidak Pernah & 34 & 49 & $83(75,5)$ & $(1,84-13,81)$ \\
\hline \multicolumn{5}{|l|}{ Menderita ISPA } \\
\hline Pernah Sakit & 20 & 5 & $25(22,7)$ & 5,71 \\
\hline Tidak Pernah & 35 & 50 & $85(77,3)$ & $(1,95-16,67)$ \\
\hline \multicolumn{5}{|l|}{ TKE } \\
\hline Kurang & 50 & 42 & $92(83,6)$ & 3,09 \\
\hline Baik & 5 & 13 & $18(16,4)$ & $(1,02-9,39)$ \\
\hline \multicolumn{5}{|l|}{ TKP } \\
\hline Kurang & 36 & 14 & $50(45,5)$ & 5,54 \\
\hline Baik & 19 & 41 & $60(54,5)$ & $(2,43-12,63)$ \\
\hline \multicolumn{5}{|l|}{ TB Orang Tua } \\
\hline Pendek & 36 & 8 & $44(40)$ & 11,13 \\
\hline Normal & 19 & 47 & $66(60)$ & $(4,37-28,3)$ \\
\hline \multicolumn{5}{|l|}{ Berat Bayi Lahir } \\
\hline Rendah & 29 & 14 & $43(39,1)$ & 3,26 \\
\hline Normal & 26 & 41 & $67(60,9)$ & $(1,46-7,31)$ \\
\hline \multicolumn{5}{|l|}{ ASI Eksklusif } \\
\hline Tidak & 41 & 17 & $58(52,7)$ & 6,54 \\
\hline $\mathrm{Ya}$ & 14 & 38 & $52(47,3)$ & $(2,84-15,06)$ \\
\hline \multicolumn{5}{|l|}{ MP-ASI } \\
\hline Dini & 41 & 17 & $58(52,7)$ & 6,54 \\
\hline Normal & 14 & 38 & $52(47,3)$ & $(2,84-15,06)$ \\
\hline \multicolumn{5}{|c|}{ Praktek Pemberian Makan } \\
\hline Kurang & 37 & 17 & $54(49,1)$ & 4,59 \\
\hline Baik & 18 & 38 & $56(50,9)$ & $(2,05-10,25)$ \\
\hline \multicolumn{5}{|l|}{ Praktek Kebersihan } \\
\hline Kurang & 29 & 14 & $43(39,1)$ & 3,26 \\
\hline Baik & 26 & 41 & $67(60,9)$ & $(1,46-7,31)$ \\
\hline \multicolumn{5}{|l|}{ Praktek Pengobatan } \\
\hline Kurang & 30 & 18 & $48(43,6)$ & 2,46 \\
\hline Baik & 25 & 37 & $62(56,4)$ & $(1,13-5,34)$ \\
\hline \multicolumn{5}{|c|}{ Ketersediaan Sumber Air Bersih } \\
\hline Tidak Layak & 5 & 3 & $8(7,27)$ & 1,73 \\
\hline Layak & 50 & 52 & $102(92,73)$ & $(0,39-7,63)$ \\
\hline
\end{tabular}


Tabel 3. Faktor Risiko Stunting ; Analisis Multivariat

\begin{tabular}{lccc}
\hline \multicolumn{1}{c}{ Variabel } & Exp $(\mathrm{B})$ & Nilai $\mathrm{p}$ & OR $(95 \% \mathrm{CI})$ \\
\hline TB orang tua pendek & 13,16 & 0,001 & $3,72-46,52$ \\
Tidak ASI eksklusif & 3,02 & 0,068 & $0,92-9,93$ \\
Frekuensi Diare & 6,33 & 0,016 & $1,40-28,62$ \\
Frekuensi ISPA & 8,99 & 0,005 & $1,94-41,51$ \\
TKP rendah & 5,87 & 0,005 & $1,70-20,20$ \\
Pengeluaran keluarga & 6,11 & 0,017 & $1,39-26,90$ \\
yang rendah & & & \\
\hline
\end{tabular}

ayah dapat menjalankan fungsinya sebagai kepala keluarga. Fungsi yang dijalankan berkaitan dengan pemenuhan kebutuhan pangan dan non pangan keluargamelalui pendapatan. Pendidikan ibu di bawah 9 tahun bukan merupakan faktor risiko kejadian stunting pada anak umur 6-24 bulan. Hasil penelitian ini sejalan dengan penelitian lain bahwa tingkat pendidikan ibu tidak berhubungan secara signifikan dengan kejadian stunting pada balita. ${ }^{9}$ Bertolak belakang dengan penelitian yang lain bahwa ibu dengan tingkat pendidikan SD berisiko untuk memiliki anak stunting ${ }^{7}$ dan ibu dengan tingkat pendidikan rendah lebih berisiko memiliki anak yang underweight. ${ }^{17}$

Hasil penelitian ini menunjukkan bahwa sebagian besar tingkat pendidikan ibu tergolong pendidikan tinggi yaitu tamat SMA. Ibu dengan tingkat pendidikan tinggi diharapkan memiliki sikap positif terhadap gizi makanan sehingga dapat membantu pemenuhan kebutuhan gizi yang cukup untuk keluarga. ${ }^{14}$ Tingkat pendidikan yang tinggi juga memengaruhi kemampuan dalam menerima informasi mengenai gizi dan kesehatan anak. Beberapa ibu mengemukakan bahwa mereka sering menonton televisi dan membaca surat kabar/majalah, dimana dari kedua media informasi tersebut mereka mendapatkan pengetahuan tentang gizi dan kesehatan anak yang baik.

Status ayah yang tidak bekerja bukan merupakan faktor risiko stunting. Hal ini tidak sesuai dengan penelitian lain bahwa ayah yangtidak bekerja merupakan salah satu faktor risiko penyebab stunting. ${ }^{7,9}$ Hasil penelitian ini juga menunjukkan bahwa ibu yang tidak bekerja bukan merupakan faktor risiko. Hasil ini tidak sejalan dengan penelitian lain bahwa ibu yang tidak bekerja akan berisiko 3,11 kali untuk memiliki anak yang stunting. ${ }^{14}$ Status orang tua yang tidak bekerja bukan merupakan faktor risiko karena pada penelitian ini sebagian besar baik ayah dan ibu memiliki pekerjaan.

Pendapatan keluarga yang rendah merupakan faktor risiko kejadian stunting pada anak umur 6-24 bulan. Anak dengan pendapatan keluarga yang rendah memiliki risiko menjadi stunting sebesar 8,5 kali dibandingkan pada anak dengan pendapatan keluarga tinggi. Penelitian lain menyebutkan bahwa Faktor risiko stunting pada anak balita di Maluku yaitu status sosial ekonomi keluarga yang rendah.,18 Alat transportasi umum yang terdapat di Kota Subulussalam yaitu becak motor. Ongkos becak yang mahal menyebabkan masyarakat membeli sepeda motor untuk memudahkan mobilitas. Biaya kredit sepeda motor dan bahan bakar menambah jumlah pengeluaran keluarga setiap bulannya. Hal ini akan semakin sulit bagi keluarga dengan pengeluaran yang rendah.

Penyakit infeksi merupakan faktor risiko stunting pada penelitian ini. Penilaian dilakukan berdasarkan apakah pernah menderita diare dan ISPA dalam 2 bulan terakhir. Hasil penelitian menunjukkan bahwa Anak yang menderita diare dalam 2 bulan terakhir memiliki risiko sebesar 5,04 kali untuk menjadi stunting dibandingkan dengan anak yang tidak pernah diare dalam 2 bulan terakhir. Hal ini sejalan dengan penelitian lain bahwa anak yang mengalami diare dalam kurun waktu 24 bulan pertama kehidupan cenderung untuk lebih pendek $1,5 \mathrm{kali}^{19}$ dan terjadi peningkatan risiko stunting sebesar 7,46 kali pada anak yang diare. ${ }^{14}$

Anak yang menderita ISPA, memiliki risiko sebesar 5,71 kali untuk menjadi stunting dibandingkan dengan anak yang tidak pernah menderita ISPA dalam 2 bulan terakhir. Sejalan dengan penelitian lain bahwa anak balita yang mengalami ISPA dalam 1 bulan terakhir lebih berisiko 3,1 kali untuk mengalami gizi buruk. ${ }^{17}$ Diare dan ISPA merupakan salah satu penyakit infeksi yang sering diderita oleh anak. Penyakit infeksi memberikan dampak negatif terhadap status gizi anak dalam hal mengurangi nafsu makan dan penyerapan zat gizi dalam usus, terjadi peningkatan katabolisme sehingga cadangan zat gizi yang tersedia tidak cukup untuk pembentukan jaringan tubuh dan pertumbuhan. ${ }^{20}$

Anak dengan tingkat kecukupan energi yang rendah, memiliki risiko sebesar 3,09 kali untuk menjadi stunting dibandingkan dengan anak yang memiliki tingkat kecukupan energi baik. Risiko semakin meningkat 5,54 pada anak dengan tingkat kecukupan protein yang rendah. Sejalan dengan penelitian lain bahwa tingkat kecukupan energi yang 
rendah merupakan faktor risiko stunting pada anak balita. ${ }^{18,21}$ Penelitian lain menyebutkan bahwa balita yang mempunyai asupan protein kurang memiliki risiko menjadi stunting sebesar 1,19 kali dibandingkan dengan balita yang mempunyai asupan protein kurang. ${ }^{18}$

Anak yang dilahirkan dari kedua atau salah satu orang tua yang pendek, memiliki risiko menjadi stunting sebesar 11,13 kali dibandingkan dengan anak yang dilahirkan dari orang tua dengan tinggi badan normal. Penelitian ini sejalan dengan hasil yang dikemukakan oleh peneliti lain bahwa memiliki orang tua yang pendek salah satu faktor risiko stunting pada balita. ${ }^{22,23,24}$

Anak dengan berat badan lahir kurang dari 2500 gram, memiliki risiko menjadi stunting sebesar 3,26 kali dibandingkan dengan anak yang lahir dengan berat badan normal. Penelitian lain menyebutkan bahwa balita yang mempunyai berat lahir rendah, memiliki risiko menjadi stunting sebesar 1,7 kali dibandingkan dengan balita yang mempunyai berat lahir normal ${ }^{18}$ dan risiko stunting akan meningkat 3 kali pada anak yang dilahirkan dengan berat badan kurang dari 2500 gram. ${ }^{25}$

Hasil penelitian ini menunjukkan bahwa proporsi stunting lebih banyak terjadi karena anak tidak diberi ASI eksklusif. Anak yang tidak diberi ASI eksklusif, memiliki risiko menjadi stunting 6,54 kali dibandingkan dengan anak yang diberi ASI eksklusif. Penelitian lain mengemukakan bahwa bahwa anak yang tidak mendapatkan ASI eksklusif akan 3,2 kali menderita gizi buruk ${ }^{26}$ sementara risiko anak menjadi stunting adalah 6,9 kali jika tidak mendapatkan ASI eksklusif. ${ }^{14}$ Faktor penyebab kegagalan pemberian ASI eksklusif di Kecamatan Penanggalan yaitu kebiasaan masyarakat dengan pemberian madu pada bayi baru lahir. Anak yang sering menangis diasumsikan karena lapar sehingga ibu memberikan makanan lain seperti air tajin, bubur saring, dan susu formula dan pengaruh keluarga yang tidak mendukung pemberian ASI eksklusif.

Anak yang diberikan MP-ASI terlalu dini memiliki risiko menjadi stunting 6,54 kali dibandingkan dengan anak yang diberikan MP-ASI sesuai dengan umur yang seharusnya. Hal ini sejalan dengan penelitian lain yaitu pemberian MP-ASI yang tepat merupakan faktor protektif terhadap kejadian balita gizi buruk. ${ }^{12}$ Pemberian MP-ASI terlalu dini merupakan faktor risiko terjadinya stunting. ${ }^{9}$ Hasil penelitian ini menunjukkan bahwa terdapat hubungan antara kegagalan ASI eksklusif dengan pemberian MP-ASI terlalu dini. Ibu yang tidak memberikan ASI secara eksklusif biasanya memberikan makanan lain sebagai pengganti ASI. MP-ASI yang biasa diberikan berupa pisang, bubur saring, susu formula, dan biskuit.
Sebagian besar anak stunting pada penelitian ini diberikan MP-ASI pada saat berumur kurang dari 1 bulan.

Hasil penelitian ini menunjukkan bahwa pola asuh yang kurang baik merupakan faktor risiko stunting pada anak umur 6-24 bulan. Pola asuh yang dinilai yaitu dalam hal praktek pemberian makan, praktek kebersihan dan praktek pengobatan. Hal ini sesuai dengan hasil penelitian lain bahwa pola pengasuhan anak berhubungan dengan kejadian stunting. ${ }^{13}$ Pola asuh yang tidak baik merupakan faktor risiko terjadinya stunting. Hasil penelitian ini menunjukkan bahwa ibu memberikan makan anak tidak memperhatikan pola gizi seimbang. Anak juga sering diberi makanan jajanan sehingga kebutuhan gizi anak tidak terpenuhi secara optimal. Praktek kebersihan anak memengaruhi pertumbuhan linier anak melalui peningkatan kerawanan terhadap penyakit infeksi. Berdasarkan pengamatan di lapangan ada sebagian ibu yang tidak mencuci tangannya saat memberi makan pada anak dan setelah membersihkan buang air besar anak. Praktek pengobatan anak berhubungan dengan kesehatan anak yang optimal.

Ketersediaan sumber air bersih yang tidak layak bukan merupakan faktor risiko kejadian stunting pada anak umur 6-24 bulan. Hal ini sesuai dengan penelitian lain bahwa prevalensi anak yang stunting meningkat pada kelompok anak yang mengkonsumsi air yang berasal dari sumur dibandingkan dengan kelompok anak yang mengkonsumsi air isi ulang. ${ }^{15}$ Status gizi balita yang kurus lebih banyak pada kelompok yang menggunakan sumber air yang tergolong buruk atau kurang memenuhi syarat kesehatan. ${ }^{27}$

Berdasarkan hasil analisis multivariat, diperoleh bahwa faktor dominan risiko stunting pada anak umur 6-24 bulan yaitu orang tua yang pendek. Anak yang memiliki kedua atau salah satu orang tua yang pendek, memiliki risiko sebesar 13,16 kali untuk menjadi stunting dibandingkan dengan anak yang memiliki orang tua dengan tinggi badan normal setelah dikontrol variabel tidak diberi ASI eksklusif, menderita diare, menderita ISPA, tingkat kecukupan protein yang rendah, dan pendapatan keluarga yang rendah.

\section{SIMPULAN}

Faktor risiko kejadian stunting pada anak umur 624 bulan di Kecamatan Penanggalan Kota Subulussalam yaitu rendahnya pendapatan keluarga, menderita diare, menderita ISPA, rendahnya tingkat kecukupan energi, rendahnya tingkat kecukupan protein, salah satu orang tua pendek, berat bayi lahir rendah, tidak diberi ASI eksklusif, MP-ASI terlalu 
dini, dan pola asuh yang kurang baik. Faktor risiko yang paling dominan terhadap kejadian stunting pada anak umur 6-24 bulan yaitu salah satu orang tua pendek.

Tingginya prevalensi stunting pada anak umur 624 bulan di Kecamatan Penanggalan Kota Subulussalam dapat diturunkan dengan Puskesmas melaksanakan program penyuluhan tentang PHBS (Pola Hidup Bersih dan Sehat) untuk mengurangi risiko diare dan ISPA. Peningkatan tingkat kecukupan energi dan protein pada anak melalui penyuluhan kepada ibu tentang pentingnya makanan bagi bayi dan balita. Penyuluhan tentang manfaat ASI eksklusif dan pemberian MP-ASI yang benar untuk menunjang keberhasilan ASI eksklusif. Penyuluhan tentang pola asuh yang baik, bagaimana ibu merawat dan menjaga anak, dan fokus kepada pemenuhan kebutuhan gizi anak.

\section{DAFTAR PUSTAKA}

1. Manary MJ, Solomons NW. Gizi kesehatan masyarakat, gizi dan perkembangan anak. Terjemahan Public Health Nutrition, Editor. Gibney, M.J, Margetts, B.M., Kearney, J.M.\&Arab, L Blackwell Publishing Ltd, Oxford. Penerbit Buku Kedokteran: 2009 dalam Fitri. Berat lahir sebagai faktor dominan terjadinya stunting pada balita 12-59 bulan di Sumatera (Analisis Data Riskesdas 2010). [tesis]. Depok: Universitas Indonesia; 2012.

2. Umeta M, West CE, Haidar J, Deurenberg P, Hautvast JG. Zinc supplementation and stunted infants in Ethiopia: a randomized controlled trial. Lancet. 2000; 355: 2021-6.

3. Bryce J, Coitinho D, Darnton-Hill I, Pelletier D, Pinstrup-Andersen P. Maternal and child undernutrition: effective action at national level. Lancet. 2008; 371: 510-26.

4. Departemen Kesehatan RI. Kecenderungan masalah gizi dan tantangan di masa datang. Jakarta; 2004.

5. Puspitasari FD, Sudargo T, Gamayanti IL. Hubungan antara status gizi dan faktor sosiodemografi dengan kemampuan kognitif anak sekolah dasar di daerah endemis GAKI. Gizi Indon. 2011; 34(1): 52-60.

6. Hartati S. Hubungan prestasi belajar dengan anak stunted di Kecamatan Pajangan Kabupaten Bantul Daerah Istimewa Yogyakarta. [tesis]. Yogyakarta: Universitas Gadjah Mada; 2011.

7. Ramli, Agho KE, Inder KJ, Bowe SJ, Jacobs J, Dibley MJ. Prevalence and risk factors for stunting and severe stunting among under-fives in North Maluku province of Indonesia. BMC Pediatrics. 2009; (9):64-73.
8. Hayati AW, Hardinsyah, Jalal F, Madanijah S, Briawan D. Determinan stunting anak baduta. WNPG X; 2012 Nov 20-21; Jakarta: LIPI; 2012.

9. Ergin F, Okyay P, Atasoylu G, Beser E. Nutritional status and risk factors of chronic malnutrition in children under five years of age in Aydin, a western city of Turkey. Turkish $\mathbf{J}$ of Pediatrics. 2007; 49: 283-89.

10. Nanthamongkolchai S, Ngaosusit C, MunsawaengsubcC. Influence of parenting styles on development of children aged three to six years old. J Med Assoc Thai. 2007; 90(5): 97176.

11. Zhou H, Wang XL, Ye F, Zeng XL, Wang Y. Relationship between child feeding practices and malnutrition in 7 remote and poor counties, P R China. Asia Pac J Clin Nutr. 2012; 21(2): 234-40.

12. Susanty M, Kartika M, Hadju V, Alharini S. Hubungan pola pemberian ASI dan MP-ASI dengan gizi buruk pada anak 6-24 bulan di Kelurahan Pannampu Makassar. Media Gizi Masyarakat Indonesia. 2012; 1(2): 97-103.

13. Astari LD, Nasoetion A, Dwiriani CM. Hubungan karakteristik keluarga, pola pengasuhan dan kejadian stunting anak usia 6-12 bulan. Media Gizi dan Keluarga. 2005; 29(2): 4046.

14. Paudel R, Pradhan B, Wagle RR, Pahari DP, Onta SR. Risk factors for stunting among children: a community based case control study in Nepal. Kathmandu University Med J. 2012; 10(3): 18-24.

15. Sarkar R, Sivarathinaswamy $P$, Thangaraj B, Sindhu KNC, Ajjampur SSR, Muliyil J, et al. Burden of childhood diseases and malnutrition in a semi-urban slum in southern India. BMC Pub Health. 2013; (13):87-100.

16. Riset Kesehatan Dasar. Badan Penelitian dan Pengembangan Kesehatan. Jakarta: Kementerian Kesehatan; 2010.

17. Bloss E, Wainaina F, Bailey RC. Prevalence and predictors of underweight, stunting, and wasting among children aged 5 and under in Western Kenya. J of Trop Pediatrics. 2004; 5(5): 260-70.

18. Fitri. Berat lahir sebagai faktor dominan terjadinya stunting pada balita $12-59$ bulan di Sumatera (Analisis Data Riskesdas 2010). [tesis]. Depok: Universitas Indonesia; 2012.

19. Checkley W, Epstein LD, Gilman RH, Cabrera L, Black RE. Effects of acute diarrhea on linear growth in Peruvian children. Am J Epidemiol. 2003; 157(2): 166-75.

20. ACF International. Interactions of: Malnutrition, water sanitation and hygiene, infections, Paris: Technical Department, Action Against Hunger International Network. 2007: 1-47. 
21. Hidayati L, Hadi H, Kumara A. Kekurangan energi dan zat gizi merupakan faktor risiko kejadian stunted pada anak usia 1-3 tahun yang tinggal di wilayah kumuh perkotaan Surakarta. Jurnal Kesehatan. 2010; 3(1): 89-104.

22. Rahayu LS. Hubungan tinggi badan orang tua dengan perubahan status stunting dari usia 6-12 bulan ke usia 3-4 tahun. [tesis]. Yogyakarta: Universitas Gadjah Mada; 2012.

23. Jesmin A, Yamamoto SS, Malik AA, Haque MdA. Prevalence and determinants of chronic malnutrition among preschool children : a crosssectional study in Dhaka City, Bangladesh. J Health Popul Nutr. 2011; 29(5): 494-99.

24. Casapia M, Joseph SA, Nunez C, Rahme E, Gyorkos TW. Parasite and maternal risk factors for malnutrition in preschool-age children in Belen, Peru using the new WHO Child Growth Standards. Brit J of Nutr. 2007; 98: 1259-66.

25. Abuya BA, Ciera J, Kimane-Murage E. Effect of mother's education on child's nutritional status in the slums of Nairobi. BMC Paediatrics. 2012; 12: 80-89.

26. Amsalu S, Tigabu Z. Risk factors for severe acute malnutrition in children under the age of five: a case-control study. Ethiop. J. Health Dev. 2008; 22(1): 21-25.

27. Supraptini dan Hapsari D. Status gizi balita berdasarkan kondisi lingkungan dan status ekonomi (Data Riskesdas 2007). Jurnal Ekologi Kesehatan. 2011; 10(2): 103-13. 